\title{
ANALYSIS OF TEACHER PERFORMANCE ON LEARNING MANAGMENT IN PRIMARY SCHOOL
}

\author{
Roos. M. S. Tuerah ${ }^{\mathrm{a}}$ \\ aDoctor of Department of Education, State University of Manado, Indonesia \\ Corresponding e-mail: roos.tuerah@gmail.com
}

\begin{abstract}
This research intends to acquire data on the influence of learning management and commitment to the performance of primary school teachers, and this research approach using quantitative and survey methods. Population research are primary school teachers in Tomohon city that add up to 700 people. With drawl of samples using the techniques Proportional Stratified Random Sampling and the number of samples obtained 195 teachers. Research data collection using the questionnaire form and test instruments. By using Path Analysis Technique (Path Analysis). The result of the research, There is direct positive influence management learning to teachers performance. Management of learning influence to teachers performance. This indicates that the improvement of teaching management by elementary school teachers will result in increased performance in teaching.
\end{abstract}

Keywords: learning management, teacher performance

\section{INTRODUCTION}

Education is a conscious effort that is planned to create an atmosphere of learning and learning process, besides, learners can actively develop their own potential. Therefore education needs to be interpreted by the values of humanity, religion, empathy, willingness to accept, willingness to help and make the world of education as a safe and better place. Thus in essence education is a human need that can provide a safe environment in order to students can develop the various potentials it has.

Studies conducted by Heyneman \& Loxley (1983) in 29 empiricalries found that among the various inputs that determine the quality of education (shown by student achievement). The role of teachers is even more important aimed to limitations of facilities and infrastructure as experienced by developing empiricalries. Research results in developing empiricalries, teachers contributed to learning achievement of $34 \%$, while management $22 \%$, learning time $18 \%$ and physical facilities $26 \%$. In industrialized empiricalries, teachers' contribution is $36 \%$, management $23 \%$, learning time $22 \%$ and physical facilities $19 \%$. Furthermore, the results of research conducted by Nana Sudjana shows that $76.6 \%$ of student learning outcomes are influenced by the performance of teachers, with details: the ability of teachers to contribute $32.43 \%$, mastery of the subject matter to give contribution of $32.38 \%$ and attitudes of teachers to subjects Contributed $8.60 \%$.
Bloom (1999) Performance is the ability of a person to be able to complete the job efficiently and effectively through the use of all the resources contained in the work environment, in case ultimately will result in optimal quality of work. Therefore, job assessment is tailored to the work context and type of work that is fundamentally related to the three dimensions of general assessment. First, the results of the implementation of individual tasks (individual task outcomes) with assessment criteria such as the quantity produced, the amount of damage and cost per unit. Second, behaviors include helping others, making suggestions for improvement, volunteering extra to make the members of the organization more effective. Third, traits include good attitude, selfconfidence, self-reliance, diligence, and good experience.

From the description above, it can be concluded that: (1) performance is a performance that can be achieved by a person in carrying out his duties of work in accordance with the authority and responsibility in an effort to achieve organizational goals with indicators of completing the task properly and correctly, Rules of work, having initiative in working, maintaining the quality of work, being well behaved and responsive to the improvement of work demands, achieving the stated goals according to the work agenda, (2) performance is the result of work (factuality, relevance, truth, equilibrium, equity and acempiricalability / Trustworthiness, interest, variety of presentation, authenticity, personal satisfaction), work completion (timeliness of process, accuracy, 
accuracy of distribution), work behavior (following scientific ethics), and mastering the professional activities of a person in charge and responsible to manage and present data and Information in various forms as consumption in Wide society.

According to Newstrom and Davis (2005), commitment in carrying out duties, or teacher loyalty, is the level of identification of a teacher with the organization and the desire to actively participate in which often reflects teacher's confidence in the mission and objectives of the school, the willingness to develop the business in the completion of their work, Keep working at the school. In this case, a good indicator of commitment is a good introduction to the task so that they are willing to develop a business in achieving goals and mission.

Bishop, Scott \& Burroughs (2010) define commitment as the relative strength of the identification of shared individuals and their engagement with organizations. The fact that, some teachers began to decline against the duties and responsibilities as educators. They focus more on how their well-being is fulfilled or the rewards of themselves can be achieved in terms of economic, social, and ethical.

The fact that the performance of teachers tend to decrease due to over-concentrate to survive in welfare issues, certification or preoccupation in follow-up education for elementary teachers who have not bachelor education as required in the Education System Act.

Learning is the process of changing behavior. However, it will be difficult to see how the process of behavior change occurs in a person, because the behavioral changes associated with changes in the nervous system and energy changes are difficult to see and touched. Therefore, the process of behavior change is a mystery or a psychologist named it as a black box.

Thus they are less able to organize and manage the learning well, in accordance with the expected stages in terms of planning, implementation, organizing and evaluation. Teachers tend not to plan the learning process well until the evaluation. As a result before the National Examination, always held additional lessons, which actually makes the students feel tired by continuing to learn. In addition, the teacher has not been able to master the learning materials so that the learning achievement of students is not in accordance with the desired. It causes the teacher was using simple learning materials, which have been prepared by the National Education Department. As a result they were not creative and innovative, to elaborated the material.
According the case, researchers are interested in conducting research in connection with the performance of teachers. Therefore, the direction of this study is to describe the level of influence between the mastery of learning materials, learning management, commitment to perform the tasks of the performance of elementary school teachers in Tomohon City consisting of 66 elementary schools. The main problem in this research is how to improve the quality of performance of elementary school teachers in Tomohon City with the focus of study seen from the learning management and commitment to perform the task.

\section{Hyphotesis}

Hypoyhesis of study could be elaborated such as:

1. The commitment of duty directly affect the performance of elementary school teachers.

2. The learning management have a direct impact on commitment to perform tasks.

3. The learning management have a direct effect on the performance of learning materials.

\section{MATERIALS AND METHODS}

\subsection{Participant}

The target population became the generalization area of the research results, were all elementary school teachers in Tomohon City scattered in 66 elementary schools consisting of 21 public schools and 44 private schools totaling as many as 700 teachers.

Furthermore, the researchers determine the size of the sample using the method proposed Isaac and Michael (Sugiyono,2007), furthermore, it can be known the sample size of 195 elementary school teachers. The determination of 195 elementary school teachers on the population was done randomly.

\subsection{Materials}

This study uses quantitative approach associative with method using path analysis technique that is analyze influence one variable to other variable. The data collection of this research using the instrument in the form of test mastery of learning materials and questionnaires. Instruments for measuring performance variables $(\mathrm{Y})$, learning management (X1), and task commitment (X2) are very frequent (score 5), often (score 4), rare (score 3 ), very rare (score 2), and Never (score 1).

The technique used in data analysis of the results of this study is the analysis of descriptions and 
inferential analysis. Descriptive analysis is used to describe the state of the research data of each variable in the form of frequency distribution, histogram, median, mode, average, variance, and standard deviation, namely: (1) description of performance variable data $(\mathrm{Y})$.

\subsection{Procedure}

Before the test had implementation to the elementary school teacher, the researcher had been arranged the instrument according their empirical study. On December, 2015 elementary school teachers in Manado city had taken test of competence. After the teachers taken the UKG (competence test of teacher), the professional of elementary school teacher had been action to analyse the impact factor according the data. The competence of data such as performance teacher, learning management and commitment task.

The competence test of data had conducted to statistical descriptive and inferential analysis. In order that the impact factor of elementary school teacher had been interpreted and give the contribution to society especially Indonesian.

\section{RESULT AND DISCUSSIONS}

This study has three steps analysis, it consists of descriptive statistic to describe variabels, dtermine the linearity correlation between variables and proofed hypothesis.

\subsection{Description of Teacher Performance Variables (Y)}

Instrument of performance variables in this study amounted to 26 items (items), with the lowest score 26 , the highest score 130 , and the average score 78 . Based on the results of empirical data processing using descriptive statistics, obtained the lowest score 80 , the highest score 119 , the average score 100.67 , mode 102, median 101, standard deviation 9.09, and variance 82.7. Furthermore, the performance variable scores are grouped in the form of frequency distributions in Table.1 and histogram is then made as shown in Figure 1.

Table 1. Frequency Distribution of Performance Variable (Y)

\begin{tabular}{ccccc}
\hline No. & Interval & $\begin{array}{c}\text { Absolute } \\
\text { Frequency } \\
\text { (f) }\end{array}$ & $\begin{array}{c}\text { Frequency } \\
\text { cumulative } \\
\text { (fk) }\end{array}$ & $\begin{array}{c}\text { Relative } \\
\text { Frquency } \\
\text { (\%) }\end{array}$ \\
\hline 1. & $80-83$ & 5 & 5 & 2,56 \\
\hline $\mathbf{2 .}$ & $84-87$ & 15 & 20 & 7,69 \\
\hline $\mathbf{3 .}$ & $88-91$ & 20 & 40 & 10,26 \\
\hline $\mathbf{4 .}$ & $92-95$ & 22 & 62 & 11,28 \\
\hline $\mathbf{5 .}$ & $96-99$ & 33 & 95 & 16,92 \\
\hline $\mathbf{6 .}$ & $100-103$ & 30 & 125 & 15,38 \\
\hline $\mathbf{7 .}$ & $104-107$ & 30 & 155 & 15,38 \\
\hline $\mathbf{8 .}$ & $108-111$ & 18 & 173 & 9,23 \\
\hline $\mathbf{9 .}$ & $112-115$ & 15 & 188 & 7,69 \\
\hline $\mathbf{1 0 .}$ & $116-119$ & 7 & 195 & 3,59 \\
\hline & Total & 195 & - & 100 \\
\hline
\end{tabular}

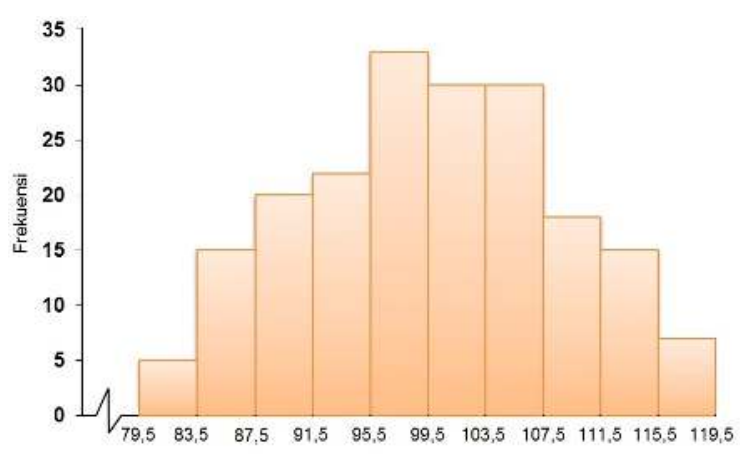

Fig.1 Performance Variable Histogram

\subsection{Description of Learning Management Variable}

Instrument of learning management variables in this research amounted to 27 items (items), so that the lowest theoretical score of 27, the highest score 135, and the average score 81. Empirical data processing results using descriptive statistics, obtained the lowest score 86, the highest score 129 , average score 108.77 , mode 108 , median 109, standard deviation 9.78 , and variance 95.59 .

Table 2. Frequency Distribution of Learning Management Variables (X1)

\begin{tabular}{ccccc}
\hline No. & Interval & $\begin{array}{c}\text { Absolute } \\
\text { Frequency } \\
(\mathbf{f})\end{array}$ & $\begin{array}{c}\text { Cumulative } \\
\text { Frequency } \\
\text { (fk) }\end{array}$ & $\begin{array}{c}\text { Relative } \\
\text { Frequency } \\
(\mathbf{\%})\end{array}$ \\
\hline $\mathbf{1 .}$ & $86-89$ & 5 & 5 & 2,56 \\
\hline $\mathbf{2 .}$ & $90-93$ & 8 & 13 & 4,10 \\
\hline $\mathbf{3 .}$ & $94-97$ & 16 & 29 & 8,21 \\
\hline $\mathbf{4 .}$ & $98-101$ & 21 & 50 & 10,77 \\
\hline $\mathbf{5 .}$ & $102-105$ & 20 & 70 & 10,26 \\
\hline $\mathbf{6 .}$ & $106-109$ & 30 & 100 & 15,38 \\
\hline $\mathbf{7 .}$ & $110-113$ & 29 & 129 & 14,87 \\
\hline $\mathbf{8 .}$ & $114-117$ & 26 & 155 & 13,33 \\
\hline $\mathbf{9 .}$ & $118-121$ & 22 & 177 & 11,28 \\
\hline $\mathbf{1 0}$ & $122-125$ & 10 & 187 & 5,13 \\
\hline $\mathbf{1 1}$ & $126-129$ & 8 & 195 & 4,10 \\
\hline
\end{tabular}

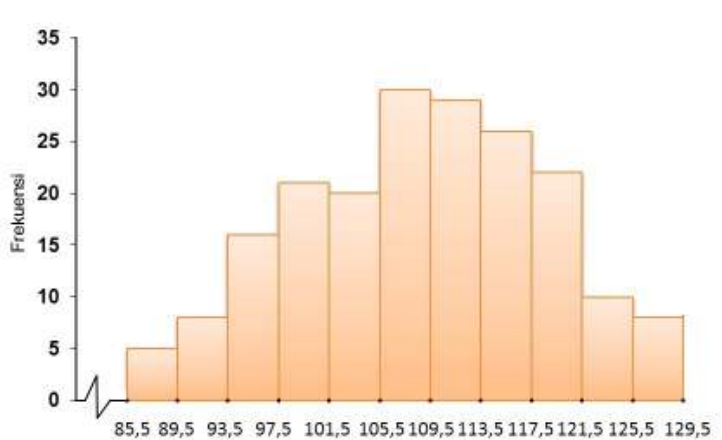


Total

195

100

Fig.2 Learning Management Variable Histogram

\subsection{Description Commitment Task Variable}

Instrument of commitment variable in carrying out duties in this research amounted to 27 items (item), so that the lowest theoretical score of 27, the highest score 135, and the average score 81 . Empirical data processing results using descriptive statistics, obtained the lowest score 93, the highest score 138, an average score of 117.51, 117 mode, median 118, standard deviation of 10.58 , and variance 111.92 . Furthermore, the performance variable scores are grouped in the form of frequency distributions.

Table 3 Frequency Distribution of Commitment Tasks (X2) Variable

\begin{tabular}{ccccc}
\hline No. & Interval & $\begin{array}{c}\text { Absolute } \\
\text { Frequency } \\
\text { (f) }\end{array}$ & $\begin{array}{c}\text { Frequecy } \\
\text { Cumulative } \\
\text { (fk) }\end{array}$ & $\begin{array}{c}\text { Relative } \\
\text { Frequency } \\
\text { (\%) }\end{array}$ \\
\hline $\mathbf{1 .}$ & $93-97$ & 5 & 5 & 2,56 \\
\hline $\mathbf{2 .}$ & $98-102$ & 14 & 19 & 7,18 \\
\hline $\mathbf{3 .}$ & $103-107$ & 20 & 39 & 10,26 \\
\hline $\mathbf{4 .}$ & $108-112$ & 25 & 64 & 12,82 \\
\hline $\mathbf{5 .}$ & $113-117$ & 23 & 87 & 11,79 \\
\hline $\mathbf{6 .}$ & $118-122$ & 36 & 123 & 18,46 \\
\hline $\mathbf{7 .}$ & $123-127$ & 28 & 151 & 14,36 \\
\hline $\mathbf{8 .}$ & $128-132$ & 24 & 175 & 12,31 \\
\hline $\mathbf{9 .}$ & $133-137$ & 15 & 190 & 7,69 \\
\hline $\mathbf{1 0}$ & $138-142$ & 5 & 195 & 2,56 \\
\hline & Total & 195 & & 100 \\
\hline
\end{tabular}

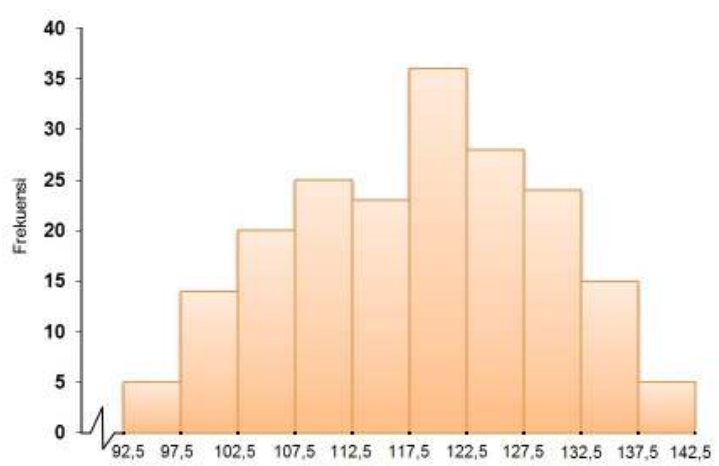

Figure 3 Commitment Task Histogram

\subsection{Significant Test and Linearity of Regression Model}

Testing the linearity of the data using the F test. To calculate the $F$ test is used SPSS program for Windows Release 19.0. The conclusion of the F test results is based on the provisions, if Fempirical is less than Ftable at the 0.05 significance level, then the data is expressed following the linear regression model, and vice versa if Fhitung is greater than Ftable at the 0.05 significance level, then the data is declared not follow Linear regression model. The results of $F$ test calculations were obtained using the SPSS for Window Release 19.0 program.

The simple linear regression model of learning management variables (X2) and teacher performance of elementary school $(Y)$ an alleged model that $\hat{\mathbf{Y}}=\mathbf{- 1 , 9 8 7}+\mathbf{0 , 9 4 1} \mathrm{X} 2$.

The data in Table 4 showed by that Fempirical $=$ 186.132 to this model is greater than Ftable $(\alpha=$ $0,01)=6,768$. The result of variance analysis (ANAOA) to this model is presented in Table 4. it could be seen that the coefisien of regression of 186.132 is greater than Ftable $(\alpha=0,01)=6,768$. It could be thus be determined that the model of the regression allegation is very significant.

Simple linear regression model of assignment commitment variable (X3) and teacher performance of elementary school (Y) the alleged model that $\hat{\mathrm{Y}}=$ $-5,337+0,899 \times 3$.

The data in Table 5. showed that Fempirical = 189.532 is greater than Ftable $(\alpha=0,01)=6,768$. it could be seen that the empirical regression of 189.532 is greater than Ftable $(\alpha=0,01)=6,768$. Thus it can be argued that the model of the alleged regression is very significant.

Significant and linearity of task commitment (X2) with teacher performance (y)

Simple linear regression model of learning material mastering variable (X1) and commitment to perform the task (X2) yielded the alleged model that $\mathrm{X} 2=8,885+1,041 \mathrm{X} 1$. The data in Table 6 shows that Fempirical $=186,525$ is greater than Ftable $(\alpha=$ $0,01)=6,768$. The results of variance analysis (ANOVA) on this model are presented in Table 4.8. In Table 4.8 it can be seen that Fempirical of regression model is 186,525 bigger than Ftable $(\alpha=$ $0,01)=6,768$. Thus it can be argued that the model of the alleged regression is very significant.

The direct influence of learning management (X1) on the performance of elementary school teachers (Y) From the calculation of path coefficient value obtained py2 equal to 0,110 and tempirical of 2,372 while ttable at level of significance 0,05 equal to 1,972 . The result of tempirical is greater than table, then $\mathrm{H} 0$ is rejected and $\mathrm{H} 1$ is accepted. Thus, it can be concluded that the management of learning has a direct positive effect on the performance of elementary school teachers.

Direct influence of commitment to perform task (X2) to performance (Y) From the calculation of 
path coefficient value obtained py3 of 0.448 and tempirical of 7.644 while ttable at the level of significance 0.05 of 1.972 . The result of tempirical is greater than table, then $\mathrm{H} 0$ is rejected and $\mathrm{H} 1$ is accepted. Thus, it can be concluded that there is a positive direct influence of commitment to perform tasks on teacher performance.

Direct influence of learning management (X2) on commitment to perform task (X1)
From the calculation of path coefficient value obtained $\mathrm{p} 32$ for 0,566 and $\mathrm{t}$ empirical equal to 14,102 while ttabel at level of significance equal to 0,05 equal to 1,972 . The result of tempirical is greater than table, then $\mathrm{H} 0$ is rejected and $\mathrm{H} 1$ is accepted. Thus, it can be concluded that there is a direct positive influence of management learning on commitment to perform the task.

Table 4. List of ANOVA for The Meaning and Linearity of Regression Y over X2 with regression equation $\hat{Y}=-1,987+$ $0,941 \mathrm{X} 2$

\begin{tabular}{|c|c|c|c|c|c|c|}
\hline Sumber Variasi & df & SS & ASS & $F_{\text {empirical }}$ & $F_{t=0,05}$ & $F_{t}=0,01$ \\
\hline Total & 195 & $1.992 .130,00$ & & & & \\
\hline Coefisien (a) & 1 & $1.976 .086,67$ & & & & \\
\hline Regression (b/a) & 1 & $15.472,39$ & $15.472,39$ & $186,132 * *$ & 3,890 & 6,768 \\
\hline Diffrence & 193 & $16.043,33$ & 83,13 & & & \\
\hline Match Tuna & 39 & $2.953,81$ & 75,74 & $0,891^{\mathrm{ns}}$ & 1,478 & \\
\hline Galat & 154 & $13.089,53$ & 85,00 & & & \\
\hline
\end{tabular}

Table 5 List of ANAVA for The Meaning and Linearity of Y Regression on X3 with regression equation $\mathrm{Y}=-5,337+$ 0,899 X3.

\begin{tabular}{lcccccc}
\hline \multicolumn{1}{c}{ Variance } & df & SS & ASS & $\mathbf{F}_{\text {empirical }}$ & $\mathbf{F}_{\mathbf{t}=\mathbf{0 , 0 5}}$ & $\mathbf{F}_{\mathbf{t}=\mathbf{0 , 0 1}}$ \\
\hline Total & 195 & $1.992 .130,00$ & & & & \\
\hline Coefisien (a) & 1 & $1.976 .086,67$ & & & & \\
\hline Regression (b/a) & 1 & $15.755,04$ & $15.755,04$ & $\mathbf{1 8 9 , 5 3 2 * *}$ & $\mathbf{3 , 8 9 0}$ & $\mathbf{6 , 7 6 8}$ \\
\hline Diffrence & 193 & $16.043,33$ & 83,13 & & & \\
\hline Tuna Match & 41 & $3.651,64$ & 89,06 & $\mathbf{1 , 0 9 2}^{\text {ns }}$ & $\mathbf{1 , 4 6 9}$ \\
\hline Galat & 152 & $12.391,70$ & 81,52 & & & \\
\hline
\end{tabular}

Table 6 List of ANAVA for Meaning and Linearity X2 Regression over X1 with regression equation X3 $=8,885+1,041$ $\mathrm{X} 1$

\begin{tabular}{lccccc} 
Variance & df & SS & ASS & $\mathbf{F}_{\text {empirical }}$ & $\mathbf{F}_{\mathbf{t}=\mathbf{0 , 0 5}}$ \\
\hline Total & 195 & $2.731 .376,00$ & & & \\
\hline Coefisien (a) & 1 & $2.711 .877,01$ & & & \\
\hline Regression (b/a) & 1 & $18.844,78$ & $18.844,78$ & $186,525^{* *}$ & 3,890 \\
\hline Diffrence & 193 & $19.498,99$ & 101,03 & & 6,768 \\
\hline Tuna Match & 39 & $3.566,37$ & 91,45 & $0,884^{\text {ns }}$ & 1,478 \\
\hline Galat & 154 & $15.932,63$ & 103,46 & & \\
\hline
\end{tabular}

\section{DISCUSSIONS}

From result of calculation known that there is a positive correlation between management of learning (X2) with performance (Y) with degree of relationship coefficient equal to 0,982 and significance test show result that coefficient significant relation. Therefore, it can be said that the performance variance $(\mathrm{Y})$ can be explained by the variance of learning management (X1). After the calculation of path coefficient between management of learning (X1) with performance (Y), the value of coefficient of path equal to 0,110 , with tempirical 2,372 bigger than Ttable value using $\alpha=0,05$ equal to 1,972 . Based on this, it can be said there is a direct influence of management of learning (X1) on performance $(\mathrm{Y})$.

From the calculation result known that there is a positive relationship between management of learning (X1) with commitment to perform task (X2) with degree of relationship coefficient equal to 0,987 and significance test show result that coefficient significant relation. Therefore it can be said that the variance of commitment to perform the task (X2) can be explained by the variance of management of 
learning (X1). After the calculation of path coefficient between management of learning (X1) with commitment to perform task (X2), obtained by coefficient value of 0,566 , with tempirical of 14,102 bigger than ttable value using $\alpha=0,05$ equal to 1,972 . Based on this, it can be said there is a direct influence of management of learning (X1) on commitment to perform task (X2). This supports the theory of Syaiful Sagala who said that the management of learning is related to the learning process of students who use the principle of education and learning theory. In this process using two-way communication is the teaching done by the teacher as an educator, and learning done by learners or students. This concept affects the commitment to carry out the task as revealed by Syaiful Sagala where a teacher needs to reflect, identify and fully involve himself in his duties at school

\section{CONCLUSION}

Learning materials mastery have a direct positive effect on the performance of elementary school teachers. This indicates that improving the learning material authority will result in improved performance of elementary school teachers.

Management of learning has a direct positive effect on commitment to perform the task. This indicates that the improvement of teaching management by elementary school teachers will result in increased commitment to perform the task.

Indicators of learning management variables in this study are measured by indicators: (1) learning planning, (2) organizing learning, (3) learning implementation, and (4) monitoring / evaluation of learning. The result of the measurement test by factor analysis shows that the four indicators are significant to explain the learning management variables. For further study, researcher could be study on teacher performance related with another factors, such as physical environment, stress managment, educational competence and motivation.

\section{REFERENCES}

[1] Arends, R. Classroom Instruction and Management. New York: McGraw-Hill, 1997.
[2] Benkgoff, "Ignoring Commitment Is Costly: New Aprroaches establish the Missink Link between Organizational Commitment and Performance," Human Relation, 1997.

[3] Bishop, Scott \& Burroughs. "Support Commitment and Employee Outcomes in a Team Environment," Journal of Management, 26,6, 2000.

[4] Blanchard, Kneth dan Paul Hersey. Management of Organization Behavior. Singapore: Prentice Hall. Inc., 1988.

[5] Davis Keith dan J. W. Newstrom. Perilaku dalam Organisasi, terjemahan Agus Dharma. Jakarta: Erlangga, 1985.

[6] De-Joy, Schaffet, Wilson, Vandenberg \& Butts. "Creating Safer Workplaces: Assessing the Determinants and Role of Safety Cimate," Journal of Safety Research, 35, 2004.

[7] Depdiknas. 2006. Pengembangan Materi Ajar (Materi 13: Sosialisasi/Pelatihan Depdiknas). Jakarta: Depdiknas,.

[8] Dowyer, Richard, Chadwick. 2003. "Gender in Management and Firm Performance: The Influence of Growth Orientation and Organizational Culture", Journal of Business Research; 56

[9] Drucker, Peter F., 1978 . Manajemen: Tugas, Tanggung Jawab, Praktek. Jakarta: Gramedia,.

[10] Goleman, D. 1995. Working with Emotional Inteligence: Kecerdasan Emosi untuk Mencapai Puncak Prestasi. Jakarta: PT. Gramedia Pustaka Utama,.

[11] Greenberg,J and Robert A. B. 2003. Organizational Behavior, Eight Edition, International. New Jersey: Pearson Education, Inc.

[12] Kambey, D. C. 2006. Teori Administrasi/Manajemen: Sebuah Intisari. Manado: Yayasan Tri Ganesha Nusantara.

[13] Koontz, H. And Weirich. 1988. Management: A System and Contingencly Analysis of Managerial Functions. New York: McGrawHill Book Co.

[14] Rivai H. Veithzal and Sylviana, M. 2010. Education Management: Analisis Teori dan Praktik. Jakarta: Rajawali Pers, 2010.

[15] Shaw, D and Abdullah. 2003. "Organizational Commutmetand Performance among Giest Workers and Citizens of An Arab Empirical," Journal of Business Research; 56. 